\title{
STUDY OF SERUM LIPIDS AND MDA LEVELS IN PREGNANCY INDUCED HYPERTENSION.
}

\author{
V. Sunanda, Jusmita Dutta, S. Sangeeta, P. Deepa, B. Prabhakar Rao
}
1. Professor, Department of Biochemistry, Prathima Institute of Medical Sciences, Nagunoor, Karimnagar, Andhra Pradesh.
2. Associate Professor, Department of Biochemistry, Prathima Institute of Medical Sciences, Nagunoor, Karimnagar, Andhra Pradesh.
3. Lecturer, Department of Biochemistry, Prathima Institute of Medical Sciences, Nagunoor, Karimnagar, Andhra Pradesh.
4. Post Graduate, Department of Biochemistry, Prathima Institute of Medical Sciences, Nagunoor, Karimnagar, Andhra Pradesh.
5. Professor, Department of Biochemistry, Prathima Institute of Medical Sciences, Nagunoor, Karimnagar, Andhra Pradesh.

\section{CORRESPONDING AUTHOR}

Dr. V. Sunanda,

Prof. in department of Biochemistry, Prathima institute of Medical Sciences, Nagunoor, Karimnagar, Andhra Pradesh, India.

E-mail: nandanil1992@gmail.com

Ph: 00919703777696

ABSTRACT: OBJECTIVE: This study has been under taken to correlate hyperlipidemia with lipid peroxidation in primigravida patients with pregnancy induced hypertension. MATERIALS AND METHODS: 60 cases of primigravida patients with pregnancy induced hypertension as test group and 20 healthy primigravida pregnant women as controls were studied. Serum lipids and MDA were estimated. Maternal blood pressures, age and baby birth weights were recorded.

RESULTS AND CONCLUSIONS: Serum cholesterol, triglycerides, LDL, VLDL and MDA levels were significantly elevated in primigravida PIH patients when compared with control subjects. $36 \%$ of primigravida patients with PIH were below 20 years of age, while only $20 \%$ of controls were below 20 years. This indicates younger maternal age is one of the factors to PIH.

KEY WORDS: PIH, lipid peroxidation, MDA, cholesterol, triglycerides, HDL, LDL.

INTRODUCTION: Pregnancy induced hypertension (PIH) is a syndrome of hypertension in pregnancy with or without proteinuria and edema. In India, the national incidence of PIH is $15.2 \%$, with the incidence in primigravida women being four times greater than in multipara 1 .

Preeclampsia is a syndrome of generalised endothelial dysfunction initiated by abnormal placentation and consequent placental under perfusion, release of cytokines, peroxidants and vasoconstriction and platelet activation ${ }^{2}$. Hypertension in pregnancy strikes mostly in the primigravida after $20^{\text {th }}$ week of gestation and frequent occurrences are seen near term. It contributes significantly to the cause of maternal and perinatal mortality and morbidity ${ }^{3}$.

Serum lipids increase significantly during pregnancy and are further elevated two fold during PIH ${ }^{4,5,6}$. Several studies have shown that lipid peroxides like malondialdehyde (MDA) are significantly elevated in mild and severe $\mathrm{PIH}^{7,8,9}$. 
This study was carried out in semirural area where early marriage of female will happen. The aim of the study was to correlate lipid peroxidation products like MDA with concentration of maternal serum lipids in primigravida patients with severity of PIH.

MATERIALS AND METHODS: The study was conducted in department of biochemistry and obstetrics at Prathima Institute of Medical Sciences situated in Nagunur village of Karimnagar district. 20 healthy subjects who had absolute normal pregnancy with normal blood pressure and 60 primiparae with PIH were included into the study. All the patients survived till the end of the study. The diagnosis of PIH was done as per the norms of American college of Obstetrics and Gynaecologists 4 which states that a) systolic blood pressure $\geq 140 \mathrm{~mm} \mathrm{Hg}$, b) diastolic blood pressure $\geq 90 \mathrm{~mm} \mathrm{Hg}$ or c) increase of $\geq 30 \mathrm{mmHg}$ in systolic pressure or d) increase of $\geq 15$ $\mathrm{mmHg}$ in diastolic pressure. PIH was diagnosed when any one of these criteria were present on at least two occasions. The study was approved by the ethics committee of the medical college.

Maternal venous blood samples were collected after over night fasting for estimation of serum cholesterol, triglycerides, HDL, LDL, VLDL and lipid peroxidation product malondialdehyde (MDA).

Serum cholesterol was estimated by CHOD-PAP enzymatic method 10

Serum triglycerides was estimated by glycerol-3-phosphate oxidase method ${ }^{11}$,

HDL was estimated by phosphotungstic acid precipitation method ${ }^{12}$, LDL and VLDL were calculated by Friedewald's formula as follows ${ }^{13}$ :

$\mathrm{VLDL}=$ triglycerides $/ 5 \mathrm{mg} / \mathrm{dl}$

$\mathrm{LDL}=$ total cholesterol $-(\mathrm{HDL}+\mathrm{TG} / 5) \mathrm{mg} / \mathrm{dl}$

MDA was estimated by thiobarbituric acid method ${ }^{14}$

Both systolic and diastolic blood pressures were recorded on two occasions separated by an interval of six hours and the patients were categorised into mild and severe PIH by taking $110 \mathrm{mmHg}$ for diastolic BP and $150 \mathrm{mmHg}$ for systolic BP as the cut off levels.

STATISTICAL ANALYSIS: The numerical data was presented as Mean \pm SD. ANOVA was applied to analyse the significance in more than two group means and ' $p$ ' value was elicited. ' $p$ ' value of $<0.05$ was considered as statistically significant. This analysis performed through SPSS version 17.

RESULTS: The study included 60 subjects of PIH as test group and 20 subjects of normal healthy pregnant women as controls.

The demographic details of PIH primigravida and control subjects are presented in table - I. The average birth weight of babies born to PIH primigravida mothers is less then that compared to controls. But, the difference was not statistically significant (Table - I). $36 \%$ of PIH patients were less than 20 years of age while only $20 \%$ of controls were below 20 years.

According to table - II, Serum cholesterol, triglycerides, LDL and VLDL were found to increased significantly in patients of PIH compared to control group(' $p$ ' $<0.001)$. But there was no much difference in HDL levels in test group and control group. Serum MDA levels were significantly increased in PIH group compared to control with 'p' value of $<0.001$. 
DISCUSSION: PIH is associated with occurrence of large placental infarcts and decreased placental growth which results in decreased placental perfusion, fetal malnutrition and decreased fetal growth. In our study, the mean birth weight of babies born mothers with PIH was less than the control subjects. Thus PIH is a contributing factor to the lower birth weight in the study population. The risk of PIH in younger maternal age group is higher in less than 25 years. Our study showed, $36 \%$ of patients were below 20 years of age. Hence in the area where this study was conducted, younger age is important factor contributing to the higher incidence of $\mathrm{PIH}^{15}$.

Several studies have reported the elevation of serum lipids during pregnancy in general and particularly during PIH ${ }^{16}$. Our study also showed similar serum lipid elevations in PIH compared to control group. In these primigravida PIH patients, the absence of increase of HDL despite the increase of other lipid parameters is a potential risk factor for atherosclerosis ${ }^{17}$.

Increased levels of MDA were found to be associated with increased serum lipid levels, indicating that PIH is associated with excessive free radical formation. Diamant.S.et al shown significant relation between increase in BP and increase in free radical activity ${ }^{18}$. It was hypothesised by many studies that the interaction of disordered lipid profile, endothelial cell damage and oxidative stress changes especially lipid peroxidation may be the cause for the development of PIH19,20.

In conclusion, younger maternal age contributes to an increased incidence of PIH among the population studied. The existence of positive correlation between the serum lipids and lipid peroxidation products, lower birth weight of the babies and BP are found in PIH.

\section{REFERENCES:}

1. Dutta D.C Text book of obstetrics, $3^{\text {rd }}$ ed. Calcutta : New central book agency (p) Ltd. 1995; 230-36.

2. Perloff D. Hypertension and pregnancy related hypertension. Cardiology clinics. 1998 Feb, 16 (1) 79-101.

3. S. Mohanthy, P.K. Sahu, M.K. Mandal, P.C. Mohapatra, A. Panda. Evaluation of oxidation stress in Pregnancy Induced Hypertension. IJCB, 2006, 21 (1) 101-105.

4. Uotila J.T., Tuimala, R.J., Aarnio, T.M.. Findings on lipid peroxidation and antioxidant function in hypertensive complication of pregnancy. Br.J.Obstet Gynecol, 1993; 100, 270-276.

5. Maseki, M., Nishigaki, I., Hagihara, M., Tomoda, Y., and Yagi, K., Lipid peroxide levels and lipid content of serum lipoprotein fractions of pregnant subjects with or without preeclampsia. Clin. Chem. Acta. 1981; 115, 155-161.

6. Wickens, D., Wilkins, M.H., Lunec, J., Ball, G and Dormandy, T.L.. Free radical oxidation (peroxidation) products in plasma in normal and abnormal pregnancy. Ann. Clin. Biochem. 1981;18, 158-162.

7. Ishihara, M.. Studies on lipoperoxide of normal pregnant women and of patients with toxaemia of pregnancy. Clin. Chem.Acta. 1978; 84, 1-9.

8. Hubel, C.A., Roberts, J.M., Taylor, R.N., Thomas, J., Rojers, G.M. and Mc Laughlin, M.L.. Lipid peroxidation in pregnancy: New perspectives on preeclampsia. Am. J. Obstet. and Gynecol. 1989; 161, 1025-1034.

9. Freud, G. and Arvan, D. Clinical biochemistry of preeclampsia and related liver disease in pregnancy, a review. Clin. Chem. Acta. 1990; 191, 123-152.

10. Allian, C.C., Poon, L. S., Chan, C.S.G., Richmond, W., Fu, P. Estimation of cholesterol. Clin.Chem. 1970; 20, 470.

11. Trinder, p. Estimation of triglycerides. Ann. Clin.Biochem. 1969; 6, 24-27 
12. Wooton, I. D. P eds.. Microanalysis in medical biochemistry $6^{\text {th }}$ edition. London, J. and A.Churchill Ltd., 1982; 177.

13. Friedwald, W.T., Levy, R.I. and Friedrickson, D.S.. Estimation of concentration of LDL in plasma, without use of preparative centrifuse. Clin. Chem. 1972; 18, 499-502.

14. Satoh, J., Kei Satoh.. Serum lipid peroxides in cerebrovascular disorders determined by a new colorimetric methods. Clin.Chim.Acta 1978; 90, 37-43

15. Yadav Shanthi, Yadav. R., and Saxena. U. Hypertensive disorders of pregnancyand perinatal out come. J. Obstet. Gynecol. India. 1997 ; July 322-30.

16. Robert, H., Knoop et al : Hyperlipidemia of pregnancy. Am. J. Obstet Gynecol 1982; 15,470 .

17. Steinberg, D., Parthasarathy, S., Carew, T.E., Khoo, J.D. and Witztum, J.L..Beyond cholesterol: Modification of LDL that increases its atherogenicity. N. Eng. J. Med. 1989; 320, 915-924.

18. Diamant, S. Lipid peroxidation in human placental tissue: General properties and influence of gestational age. Biol. Reprod. 1980; 23, 776-81.

19. Stacie,E., Geller, Shirin Ahmed and Monique, L. Brown. International classification of diseases- $9^{\text {th }}$ version coding for preeclampsia. How accurate is it? American Journ. Of Obst. \& Gynec. 2004; 190, 1629- 1634.

20. Jennifer, C., Dempsey, Michelle A., Williams and Wendy, M. Leisenring. Maternal birth weight in relation to plasma lipid concentrations inearly pregnancy. American Journ. Of Obst. \& Gynec. 2004; 190, 1359-1368.

TABLE : 1

Demographic details of primiparous PIH patients and control subjects

\begin{tabular}{|lcccc|}
\hline \multicolumn{4}{l}{ PIH patients $(\mathrm{n}=60)$} & \multicolumn{3}{l|}{ Controls (n=20) } \\
\hline Parameter & Mean \pm SD & Range & Mean \pm SD & Range \\
\hline Age (years) & $21.37 \pm 3.16$ & $18-28$ & $21.57 \pm 3.00$ & $19-30$ \\
Systolic BP & $142.78 \pm 7.5$ & $136-160$ & $108 \pm 4.99$ & $90-120$ \\
(mm Hg) & & & & \\
$\begin{array}{l}\text { Diastolic BP } \\
\text { (mm Hg) }\end{array}$ & $104.65 \pm 8.4$ & $90-120$ & $74.4 \pm 4.5$ & $68-80$ \\
$\begin{array}{l}\text { Baby birth } \\
\text { weight(gms) }\end{array}$ & $2220.8 \pm 252.4$ & $1850-2700$ & $2745 \pm 301.5$ & $2250-3250$ \\
\hline
\end{tabular}


Table - II

Serum lipids and MDA in PIH patients and controls :

\begin{tabular}{|l|l|l|l|l|}
\hline Parameter & $\begin{array}{l}\text { Controls } \\
\text { Mean } \pm \text { SD }\end{array}$ & $\begin{array}{l}\text { Mild PIH } \\
\text { Mean } \pm \text { SD }\end{array}$ & $\begin{array}{l}\text { Severe PIH } \\
\text { Mean } \pm \text { SD }\end{array}$ & Significance \\
\hline Cholesterol & $224.25 \pm 10.9$ & $254.8 \pm 11.87$ & $310.15 \pm 15.71$ & $\mathrm{p}<0.0001$ \\
Range $(\mathrm{mg} / \mathrm{dl})$ & $208-236$ & $240-276$ & $286-334$ & \\
\hline HDL & $60.9 \pm 5.9$ & $59.3 \pm 5.13$ & $60.85 \pm 3.43$ & $\mathrm{p}<0.084$ \\
Range $(\mathrm{mg} / \mathrm{dl})$ & $52-72$ & $48-80$ & $48-86$ & \\
\hline LDL & $120.05 \pm 13.44$ & $145.65 \pm 13.46$ & $197.95 \pm 16.91$ & $\mathrm{p}<0.0001$ \\
Range(mg/dl) & $99-159$ & $127-179$ & $175-229$ & \\
\hline VLDL & $42.8 \pm 1.96$ & $49.85 \pm 2.66$ & $49.85 \pm 2.64$ & $\mathrm{p}<0.0001$ \\
Range(mg/dl) & $40-46$ & $44-55$ & $46-56$ & \\
\hline Triglycerides & $213.30 \pm 10.72$ & $249.55 \pm 13.0$ & $249.25 \pm 13.41$ & $\mathrm{p}<0.0001$ \\
Range(mg/dl) & $198-228$ & $222-264$ & $232-278$ & \\
\hline MDA & $2.60 \pm 0.99$ & $3.13 \pm 1.85$ & $3.40 \pm 1.87$ & $\mathrm{p}<0.001$ \\
Range(nM/dl) & $2.41-2.74$ & $2.90-3.40$ & $3.10-3.60$ & \\
\hline
\end{tabular}

\section{Table - III}

Age distribution in controls and PIH cases :

\begin{tabular}{|l|l|l|}
\hline Age & $\begin{array}{l}\text { Controls } \\
\mathbf{n = 2 0}\end{array}$ & $\begin{array}{l}\text { PIH cases } \\
\mathbf{n = 6 0}\end{array}$ \\
\hline$\leq 20$ years & 04 & 22 \\
& $20 \%$ & $36 \%$ \\
\hline $20-25$ years & 10 & 24 \\
& $50 \%$ & $40 \%$ \\
\hline
\end{tabular}

